This is an electronic reprint of the original article. This reprint may differ from the original in pagination and typographic detail.

Author(s): Tervo, Hannu

Title: $\quad$ Self-employment transitions and alternation in Finnish rural and urban labour markets

Year: $\quad 2008$

Version:

Please cite the original version:

Tervo, H. (2008). Self-employment transitions and alternation in Finnish rural and urban labour markets. Papers in Regional Science, 87(1), 55-76.

https://doi.org/10.1111/j.1435-5957.2007.00150.x

All material supplied via JYX is protected by copyright and other intellectual property rights, and duplication or sale of all or part of any of the repository collections is not permitted, except that material may be duplicated by you for your research use or educational purposes in electronic or print form. You must obtain permission for any other use. Electronic or print copies may not be offered, whether for sale or otherwise to anyone who is not an authorised user. 
Tervo H. (2008) Self-employment transitions and alternation in Finnish rural and urban labour markets. Papers in Regional Science Vol 87 



\title{
Self-employment transitions and alternation in Finnish rural and urban labour markets
}

\author{
Hannu Tervo \\ University of Jyväskylä
}

\begin{abstract}
This paper deals with the transitions and alternation between self-employment, paid-employment and non-employment in Finland in 1987-1999, paying special attention to differences in self-employment dynamics between areas characterized by different labour market conditions, viz. rural and urban locations. Markovian analysis reveals significant differences by the type of area in the processes of transition between the three labour market states. Alternation between self-employment and other labour markets states turns out to be greater in rural than urban areas. Five major types of alternating working careers are identified. The type of area is importantly related to alternating working careers even when all the important variables describing personal and family characteristics are included in the models.
\end{abstract}

JEL- classification: J23, J24, J62, M13, O18, R23

Key words: self-employment dynamics, alternation, labour markets, urban and rural, Markovian analysis

\section{Introduction}

Regional variation in entrepreneurship or self-employment is wide in Finland (Niittykangas, Storhammar and Tervo 1994; Niittykangas 2003) as elsewhere (Malecki 1997). In Finland, self-employment is more common in rural locations than in urban locations (Alanen 1997; Niittykangas 1999). ${ }^{1}$ Employment conditions may account for this (cf. Carrasco and Ejrnæs 2003). Rural areas present fewer paid-employment opportunities than urban areas. Individuals in a small, dispersed labour market may be pushed into self-employment if they see no other realistic options. Self-employment may offer individuals normally seen as marginalised in the labour market a viable alternative to wage work. Thus, in many cases, the large number of small firms in rural areas can be interpreted as the outcome of a lack of employment opportunities in other firms or sectors rather than as the pull of the market. ${ }^{2}$ It can also be

In contrast to Finland, urban agglomerations have a higher level of entrepreneurial activity than rural areas in many countries (Wagner and Stenberg 2002; Curran and Storey 1993). Arguments can be made both for and against the advantages of entrepreneurship in urban relative to rural locations. The empirical evidence is mixed (see Parker 2004).

Type of business and motivation for starting a business may, of course, differ greatly within any given area. For example, Curran and Storey (1993) argue that people establishing businesses in rural areas place a greater emphasis upon 'life style' - they may set up a craft or very specialized type of business - than those in urban areas. 
presumed that alternation between self-employment, paid-employment and non-employment (whether unemployed or out of the labour force) is more common in areas in which paid work is scarce than in areas which offer varied employment opportunities.

While micro-econometric research on the economics of self-employment has expanded - for example, the decision to enter or leave self-employment has now been widely studied (see e.g. Kuhn and Schuetze 2001 or Parker 2004; for Finland Johansson 2000; Kangasharju 2000; Uusitalo 2001, Hyytinen and Ilmakunnas 2004, Niittykangas and Tervo 2005, Tervo 2006) few in-depth studies of the alternation between self-employment, paid-employment and non-employment have been published (see, however, Holm and Onnela 2004). It is, however, important to know how widespread transitions and alternation between different labour market states are, why these take place and in which labour markets particularly. This paper deals with the transitions and alternation between different labour market states in Finland during 1987-1999, paying special attention to differences in self-employment dynamics between areas characterized by different labour market conditions, viz. rural and urban locations.

The paper is concerned with the situation in Finland. Due to rapid economic expansion and structural change, rural areas in Finland have been losing population for a long time. Moreover, rural Finland is extremely sparsely populated by European standards. Together with vigorous technological advances in agriculture and forestry the rapid urbanization and industrialization processes that Finland has been going through have had the effect of centralizing both economic activity and population (Tervo 2005). This process has been underway for many decades now, but it gained extra impetus in the late 1990s. The 1990s were a time of very rapid structural change. While the recession years in the early 1990s deeply affected every region in Finland, the recovery, based on the export and information technology industries, was felt very unevenly across the country. New jobs were mainly created in the largest urban centres. As a result, in 2000 the number of jobs was at pre-recession levels in only six regions out of 82. Employment rates (the proportion of the working-age population who are employed) vary widely between regions; for example, in 2000 this rate ranged from 58\% to $74 \%$ (national rate $66 \%$ ).

To accomplish the aim of this paper - to describe regional variation in self-employment dynamics and alternation between labour market states in Finland during 1987-1999 - areas are divided into two groups according to their degree of urbanisation. The analysis is based on a one-percent random sample drawn from the official census and longitudinal employment statistics. The data represent a sample of the population aged 18-52 in 1987, the first year of the study period.

Transitions between labour market states are analysed as a Markov process among three such states: employment in the wage and salary sector, self-employment and non-employment. The results show that transition probabilities between these states differ significantly between rural and urban areas. Flows into and out of self-employment indicate that the relative number of individuals who have made several transitions and changes in their working careers is bigger in rural than in urban areas. Cluster analysis revealed five major types of alternating working careers, all of which proved to be more common in rural than in urban areas. Multivariate estimations based on logit and multinomial logit models showed that the type of area - urban vs. rural - is of great importance in explaining alternating working careers, even when all the important variables describing personal and family characteristics are included in the model. In all, the results illustrate the complexity of the functioning of regional labour markets and give an insight into the role of environmental and individual factors in the shaping of varied careers. 
The paper is organized as follows. First, theoretical issues related to the alternation between different labour market states in different regions are introduced. Second, a data description is given and the features of rural and urban areas in Finland are presented. Third, transitions between labour market states are analysed. Fourth, working career paths are examined and the importance of the type of area and individual characteristics are analysed. Finally, some concluding remarks and policy implications are presented.

\section{Theoretical issues}

The theoretical background of this study rests on human capital theory and the utility maximising paradigm (Knight 1921; Becker 1975; Evans and Leighton 1989a and 1989b; Tervo and Niittykangas 1994a; Taylor 1999), and on Jovanovic's (1982) dynamic selection model. Entrepreneurs have imperfect information about their innate abilities; these they can learn about only by trying entrepreneurship. Individuals less suited to self-employment give up quite soon. The longer an individual has been self-employed the more likely (s)he is to continue. The dynamic selection model emphasizes the importance of dynamics, with entrepreneurs learning about their abilities to compete and survive in the market post-entry (Taylor 1999; Parker 2004).

The utility maximizing paradigm predicts that individuals choose the occupation that offers the greatest expected utility. A rational individual compares the utility of his/her current labour market state with the utility (s)he can obtain in other states in each period, and makes the decision whether to continue in the current state accordingly. The utility maximizing approach should not be understood too literally. In a world of uncertainty and imperfect information, individuals will weigh up the pros and cons of continuing in their current state intuitively only (Tervo and Niittykangas 1994a). As many factors play a part in the determination of anticipated returns, these returns will be a subject to a constant process of adjustment. Individuals' perceptions of their returns may also suddenly alter in response to change in certain important factors.

Individuals differ in their attitudes to job attributes such as effort, risk or independence which explain their career choices (Lévesque, Shepherd and Douglas 2002). Some individuals choose to be self-employed while others prefer paid-employment. Individuals' choices between paid work, self-employment and non-employment are not always predetermined, and some may switch from paid-employment to self-employment or non-employment, and the other way around. It can be assumed that people choose a career path that maximizes their overall utility (Lévesque et al. 2002). Consequently, changing attitudes towards job attributes or changing situations may affect career choices.

Thus, self-employment often becomes episodic (Carroll and Mosakowski 1987). An individual's choice of labour market state is subject to continued revision as his/her situation changes. If the present value of the net expected benefits from continuing in self-employment is positive, the self-employed individual will not exit the market, but if it is negative, (s)he will quit. It should also be noted that the continuation of an individual in self-employment is not necessarily equivalent to the survival of the original business, as an individual can remain self-employed while opening and closing successive businesses (Parker 2004). Part of the process of firm turnover involves the same persons, i.e. serial entrepreneurs, entering and exiting entrepreneurship repeatedly (Hyytinen and Ilmakunnas 2006). 
It is well-known that many personal factors such as gender, age, education and family relations as well as institutional factors affect choices between different employment options (Parker 2004). We hypothesise that such individual characteristics are related to transitions and alternation between different labour market states. The effect of many individual characteristics may, however, vary depending on the type of entrepreneurship. A distinction can be made between "opportunity-driven" and "necessity-based" entrepreneurship (Wennekers, van Stel, Thurik and Reynolds 2005). In principle, founders of new firms can take advantage of a recognized opportunity or start a business out of necessity when they have limited, or no other, employment opportunities. Opportunity recognition is a defining element of entrepreneurship, for which reason self-employed individuals who start a new firm out of necessity need to identify opportunities and try to exploit them successfully. ${ }^{3}$ It can be assumed that the majority of individuals who start a business out of necessity and have alternation in their working careers will be older males with a family and children and low education. Opportunity-driven entrepreneurs, in turn, tend to be well-educated individuals, of both sexes with specialized education and/or good work experience.

Our main hypothesis is that career choices are affected by environmental factors. If employment opportunities remain low in the local labour market, as they are in rural areas, necessity-based entrepreneurship increases (Niittykangas and Nenonen 1994). Individuals who would otherwise prefer to work in paid-employment are "pushed" into establishing their own business ventures. Even if the expected utility from entrepreneurship is not high, it will be enough if it is higher than the expected utility of the non-entrepreneurship option: seeking a job (in vain), remaining unemployed or non-employed or migrating to another region. The last option is often difficult for individuals residing in depressed regions, in particular because of differentials in house prices (Banerjee and Newman 1993). Individuals cannot move as workers from depressed to growth regions because house prices are too high in the growth region to make this feasible (Parker 2004). Under these circumstances, individuals may consider the formation of a business as their best choice or, failing that, the least unsatisfactory choice.

In addition to necessity-based entrepreneurship, there are at least three other factors which may explain differences in self-employment dynamics in local labour markets, viz. previous labour market experience, deteriorating entrepreneurial talent and role models. First, the role of previous labour market experience may account for the existence and shaping of varied careers between different labour markets. Several studies show that those with more unstable work histories, including periods of past unemployment, are significantly more likely to enter self-employment and to be self-employed (Evans and Leighton 1989a; Carrasco 1999; Uusitalo 2001; Ritsilä and Tervo 2002; Parker 2004). For these reasons, alternation between self-employment and other labour markets states may develop in rural labour markets more commonly than in urban labour markets.

Second, entrepreneurial talent may develop to a lower level in depressed than in growth regions. This is because weak employment conditions also push less educated individuals

Global Entrepreneurship Monitor (GEM) results from Finland show that the vast majority of early-stage entrepreneurs are seeking to take advantage of business opportunity, while the level of necessity-based entrepreneurial activity, although it has been increasing recently, remains low (Heinonen, Kovalainen and Pukkinen 2006). It is, however, notable, that a relatively large proportion of individuals possess both motives simultaneously in Finland. 
towards self-employment. Many studies have shown a positive relationship between business survival and an entrepreneur's human capital (Taylor 1999; Kangasharju and Pekkala 2002). As education levels differ, this gives rise to the prediction that the self-employed in depressed regions are less likely to survive than those in growth regions who on average are better educated. Self-employment may become a stopgap that people use until they find a paid job, implying significant entry and exit movements, especially in depressed regions (Lin, Picot and Compton 2000). Alternation between different employment options will also be likely to increase.

Third, role models are also important. Regions with strong traditions of entrepreneurship may be able to perpetuate them over time and across generations (Parker 2004). Numerous studies have shown that those individuals who have experience in small firms, either as workers or as members of an entrepreneurial family, will be more likely so set up in business than other individuals (Storey 1994; Tervo and Niittykangas 1994a; Niittykangas and Nenonen 1994). Traditionally, rural locations in Finland have been characterized by agricultural enterprises and small firms, which creates a good seedbed for entrepreneurship, although these locations suffer from low levels of demand and opportunities for entrepreneurship remain unfavourable. Entrepreneurs in rural locations may keep their heads above water for some time, but before long they may have to give up and, if an opportunity arises, move to wage-work or out of the labour market, while entrepreneurs in high demand locations forge ahead.

The specification and understanding of regional entrepreneurial environments remains a complex issue (Moyes and Weasthead 1990; Reynolds, Storey and Westhead 1994; Malecki 1997). In addition, the issue of the kinds of environments that influence business failure has rarely been addressed (Westhead and Birley 1994; Tervo and Haapanen 2005). Our hypothesis is that self-employment dynamics, i.e. transitions and alternation between self-employment and other labour market states, is greater in rural than in urban locations in Finland. Taken together, fewer paid-employment opportunities and a long-standing entrepreneurial tradition especially increase the relative attractiveness of self-employment in the Finnish countryside, which increases flows into self-employment. On the other hand, flows out of self-employment also increase since rural locations suffer from low levels of demand and weaker entrepreneurial talent. As a result, alternation between different labour market states, as well as self-employment dynamics, becomes greater in rural than urban locations.

\section{Data description}

\section{The data set}

Since 1970, Statistics Finland has compiled a population census every five years; since 1990 the census has been entirely register-based. By matching personal identifiers across the censuses, Statistics Finland has constructed a Longitudinal Census File with panel data on the entire population of Finland at five-year intervals from 1970 onwards. In addition, since 1987, Statistics Finland has maintained the Longitudinal Employment Statistics File, which is updated annually. Since the same personal identifier is adopted in both the census and the longitudinal employment statistics, the two data sets can be merged, providing panel data on each resident of Finland for 1970, 1975, 1980, 1985 and then annually from 1987 onwards. This data has a very low attrition rate. 
The Longitudinal Census File holds very rich information on individuals' educational attainments, labour market performance, family characteristics and many other variables. This data also allows individuals' working careers and their choices between different labour market states to be followed. A drawback related to performing a regional analysis is that, owing to Finland's data protection legislation, Statistics Finland does not give exact information on region of domicile. Statistics Finland adds, however, to the data file certain variables which give limited information on the nature of the municipalities and local labour market areas in which individuals reside, e.g. the degree of urbanisation.

The data set used in this paper is drawn from the Longitudinal Census File. It is a one-percent random sample from this file. The total number of individuals in the last year of the study period is 49337 . The sample is restricted in two ways:

1. Age-restriction. The individuals included in the sample need to be at least 18 years of age in the first year of the study period, 1987, and not aged over 64 years in the last year of the period, 1999. Thus, the range is 34 years. In addition, to enable an individual to be followed up, there must be complete data on that individual throughout the period. Thus, those who died or emigrated during the period are eliminated from the sample. The number of individuals in the sample who meet these conditions is 24259 .

2. Industry-restriction. Individuals who worked in the primary sector are excluded from the sample. Their number is 1995 . This restriction is necessary to eliminate farmers and other agricultural entrepreneurs from the analysis owing to the special characteristics of self-employment in agriculture. The concept of self-employment is more vague in agriculture than in other industries (Blanchflower 2000). Limiting the sample in this way, of course, means the elimination of relatively greater number of individuals from rural than urban areas.

The size of the sample is 22264 and it thus represents a random sample of the population aged 18-52 in 1987 who continued to reside in Finland up to 1999 and who did not work in primary production. The sample is also restricted in relation to migration between urban and rural areas, but we will come to this later.

\section{Definition of self-employment and other labour market states}

Defining entrepreneurship is a difficult task (cf. Parker 2004). This analysis is based on the Longitudinal Census File, hence the concept of self-employment directly follows from the statistical definitions used by Statistics Finland (see Statistics Finland 2001). The central variable in this regard is "occupational status" which describes the position of the employed in the labour market: wage and salary earners, and entrepreneurs, which unfortunately cannot be divided into employers and self-employed (sole entrepreneurs). The category of entrepreneurs also comprises unpaid family workers. If an individual is not employed, (s)he belongs to a third category, non-employed. The non-employed are either unemployed or outside the labour force. The data on occupational status is based on the person's national insurance status and wage, salary and/or entrepreneurial income received. For a person to be classified as an entrepreneur, it is required that (s)he had a self-employed person's pension insurance during the last week of the year and, if the person is also in an employment relationship, an income from entrepreneurship in excess of wage income (for details, see Statistics Finland 2001).

Because self-employment is fundamentally a statistical concept used in labour market statistics and national accounting, great diversity can be found among those in this category (Johansson 2000). As is well-known, there exists a "grey area" between paid-employment and 
self-employment. For example, people may be self-employed by definition but share many of the features of dependent paid employees. Examples of workers in the 'grey area' include salespersons on commission, freelancers, home-workers, tele-workers and unpaid family workers (Parker 2004).

\section{Urban and rural areas}

Urban and rural areas are defined on the grounds of the degree of urbanisation of the municipality in which an individual resides. This piece of information is given by Statistics Finland in the sample, although the identifier of the municipality is not given.

If the proportion of people within the municipality who live in urban settlements is $80 \%$ or above, the municipality in our analysis is classified as an urban area. Otherwise it it classified as rural. An urban settlement refers to a cluster of buildings which are less than 200 metres apart from each other and which together house at least 200 people. In defining an urban settlement, Statistics Finland takes into account not only residential but also business, office and industrial buildings. Administrative divisions are irrelevant. ${ }^{4}$ In our sample, $32.9 \%$ of the individuals were from rural areas in 1987, while by 1997 the proportion had fallen to $31.5 \%$.

When analysing the transitions between labour market states in rural and urban areas, individuals whose type of area is unknown $(n=546)$ or changes during the study period (migrated from rural to urban areas or vice versa, $n=2504$ ) were excluded from the data set. Otherwise comparisons between rural and urban areas would have become distorted. After these exclusions, the number of individuals is 19214 , of which 5725 were resident in rural areas and 13489 in urban areas.

In general, Finnish urban populations have shown a strong increase, while rural areas have lost people despite overall population growth. The age and education structures of the population favour urban areas: urban areas have more educated and younger populations compared with rural areas. The three labour market measures shown in Table 1 indicate a worse employment situation in rural than in urban locations. The employment rate is somewhat lower and self-sufficiency in jobs clearly lower in rural than in urban areas. The latter measure indicates that the number of jobs compared with the number of employed in an area is notably smaller in rural areas. The most striking difference between the two areas is in the dependency rate: the number of unemployed persons and persons outside the labour force for each employed person is clearly bigger in rural than in urban areas. The maximum value of this ratio is as high as 2.80 among rural municipalities, while it is "only" 1.80 among urban municipalities. In all, these figures clearly demonstrate the relative lack of employment opportunities in rural locations.

$==$ Table 1 around here $==$

4

Statistics Finland has a classification which allows for yet finer distinctions between urban and rural areas than the classification used here. The classification divides municipalities into three categories: urban-type municipalities, densely populated municipalities and rural-type municipalities (Statistics Finland 2001). In addition to the degree of urbanisation, the classification is also based on the population of the largest urban settlement. Unfortunately, the first year for which this variable is available in our data set is 1995 , hence the variable could not be used here. In practice, however, the differences between the classifications are not wide. 
Figure 1 shows how the non-agricultural self-employment rates evolved over the study period 1987-1999. The self-employment rate is the rate of self-employed to all employed. ${ }^{5}$ First, a distinct difference can be seen between rural and urban locations. On average, the self-employment rate over the period has been twice as high in rural than urban locations. If we relate the proportion of self-employed persons to the total population (employed + non-employed) aged 18-52 in 1987, the difference is no longer as great. This is due to the bigger proportions of the non-employed in rural locations. Second, there is a different trend in the two areas: while the self-employment rate shows a slightly upward trend in urban areas (from 5.9\% to $7.9 \%$ ), in rural areas the self-employment rate first increases, peaks in the deepest year of the recession, 1993 (16.8\%), and thereafter falls, ending up at $12.1 \%$, which is, coincidently, precisely the same rate as in the first year of the period.

$==$ Figure 1 around here $==$

\section{Transitions between labour market states: a Markov analysis}

Figure 1 above showed that the self-employment rate increased over the study period in urban areas, while in rural areas it first increased and then decreased. There is, however, much "intra-area dynamics" in this development: new entrepreneurs spring up, while old ones give up. In general, firm births and deaths can be interpreted as the inevitable consequences of industrial evolution and long-term regeneration (Tervo and Niittykangas 1994b). Schumpeter (1966) described this process as one of "creative destruction", in which the economic structure is continually revolutionized from within, as the old structure is destroyed and a new one created. High turbulence, i.e. the flux created in the total composition of a sector or industry caused by flows of births and deaths (see e.g. Beesley and Hamilton 1984 or Audretsch 1990), is usually found in more innovative or newer industries. High entry and exit rates may also follow from necessity if employment opportunities remain low in the region and alternation between selfemployment and paid-employment increases.

Figure 2 shows how each year the number of flows into and out of self-employment are notably greater than the net change. The rate of turbulence is high in both urban and rural areas. Figure 2 also reveals the sources of inflows and destinations of outflows. In both areas, inflows from paid-employment to self-employment are greater than inflows from non-employment to self-employment, especially during the initial years of the study period before the severe recession of the early 1990s. The difference in favour of paid-employment is especially noticeable in urban areas. This is the main entry mechanism to self-employment. In the deepest years of the recession, however, the flows from non-employment exceeded the flows from paid-employment.

$==$ Figure 2 around here $==$

The self-employment rates were calculated in the sample and reveal the non-agricultural self-employment rates among the population aged 18-52 in 1987. Since the sample is random, the results can otherwise be generalized across the population. 
The Markov chain analysis allows for a deeper analysis of the transitions between the three labour market states (cf. Kuhn and Schuetze 2001). The transition matrix can be estimated by a maximum likelihood approach (Bickenbach and Bode 2003). Elements $\left(\hat{p}_{i j}\right)$ of each $3 \times 3$ matrix yield the empirical probability that an individual in state $i$ at time $t$ will be in state $j$ at time $t+1$. Separate $P$ matrices are reported by the type of area (Table 2). In estimating the transition probabilities it has been assumed that the underlying process of change can be described in terms of one-step transitions, i.e. that the state occupied by an individual at time $t$ depends only on that individual's state at time $t-1$. We also report the ergodic distribution of individuals across these three states under the assumption that the transitions among the labour market states are governed by a Markov process, i.e. that there is no state dependence. This ergodic distribution is the fraction of the population that would occupy each of these labour market states if the transition matrix $P$ applied to annual transition rates indefinitely. ${ }^{6}$ These steady-state distributions should be interpreted as a characterization of tendencies in the study period, not as forecasts of future developments. We also report a steady-state rate of self-employment for each transition matrix, as implied by the ergodic distributions across the states. Comparisons of ergodic, initial and final distributions are presented in Table 3.

Table 2 clearly reveals a considerable amount of dynamics in the labour markets, although over the one-year horizon the predominant feature is, naturally, high persistence. One measure that provides a summary of the amount of mobility in the distribution is the index $S$ introduced by Shorrock (1978, see Rey 2004):

$$
S=[k-\operatorname{Tr}(P)] /(k-1),
$$

where $P$ is the transition matrix, $k$ shows the number of states and $T r$ indicates the trace operator. The sum of the eigenvalues (diagonal entries) forms the trace of the matrix. The higher the index, the more mobility there is in the matrix. The range in our cases is $[0,1.5]$. The values of this index for the annual transitions in urban and rural labour markets from Table $2 \mathrm{~A}$ are 0.220 and 0.219 , respectively. They are fairly low, indicating persistence. The values of Shorrock's index for the 12 -year transition from 1987 to 1999 are 0.693 and 0.654 , respectively. Accordingly, the estimated long-run models show a less evident trend to persistence. These values show slightly lower mobility in rural labour markets. This difference mainly follows from the higher persistence in the state of non-employment in rural areas. In the state of paid-employment the persistence is even lower in rural than in urban areas, and in the state of self-employment it is about the same in both areas. Thus, Shorrock's measure of mobility provides only one view of the evolution of the distribution, as it is merely based on the sum of the diagonal entries in the Markov matrices.

$==$ Table 2 around here $==$

6

The ergodic distribution is calculated as the eigenvector $q$ associated with the unit eigenvalue such that $P q=q$. By definition, $q$ must sum to one. 
Table 2 also presents the results of the tests for homogeneity in the spatial dimension in which we compare the transition matrix for rural areas to that of urban areas (cf. Bickenbach and Bode 2003). The $\mathrm{H}_{0}$ is that the transition probabilities in rural and urban areas do not differ from each other against the $\mathrm{H}_{\mathrm{a}}$ of transition probabilities varying across regions. The test is performed by using the chi-square statistic $Q^{(R)}$ for a comparison of these two sub-samples in which

$$
\mathrm{Q}^{(\mathrm{R})}=\sum_{i=1}^{N} \sum_{j \in B i} n_{i}(r)\left[\left(\hat{p}_{i j}(r)-\hat{p}_{i j}(u)\right)^{2} / \hat{p}_{i j}(u)\right] \sim \operatorname{asy} \chi^{2}\left\{\sum_{i=1}^{N}\left(c_{i}-1\right)\left(b_{i}-1\right)\right\}
$$

where $r$ refers to rural areas and $u$ to urban areas, $\hat{p}_{i j}$ denotes the probability of transition from the $i$-th to the $j$-th class estimated from the entire sample $(i, j=1, \ldots, N=3), n_{i}(r)$ denotes the absolute number of individuals initially falling into the $i$-th state in rural areas, $c_{i}$ is the number of regions (=2) and $b_{i}$ is the number of positive entries (=3) in set $B_{i}$ (the $i$-th row of the matrix). The chi-square test statistics can also be used to compare only single rows in the transition matrices for rural areas to the corresponding rows in the matrix for urban areas (Bickenbach and Bode 2003).

Using the chi-square statistic, we obtain $Q=26.97$ which clearly rejects the $\mathrm{H}_{0}$ of spatial homogeneity ( $p<0.001,6$ degrees of freedom). The same result can be obtained in the analysis of the 12-year transition: the chi-square statistic gives $Q=86.03$ ( $\mathrm{p}<0.001,6$ degrees of freedom). Thus, we obtain the important result that the transition probabilities for rural and urban labour markets differ significantly. When testing for the spatial homogeneity of single rows, the $\mathrm{H}_{0}$ can be rejected in all cases other than the states of self-employment and non-employment in panel A of the table. For self-employment, the chi-square statistic $Q$ is only 0.49 ( $\mathrm{p}=0.783,2$ degrees of freedom), while for non-employment it is higher, being 5.90, but still insignificant ( $p=0.052,2$ degrees of freedom). In the analysis of the 12-year transition, the $\mathrm{H}_{0}$ of spatial homogeneity can also be rejected in the cases of self-employment and non-employment. We can further make two interesting findings concerning self-employment. First, the probabilities of transiting to self-employment are greater in rural than in urban locations. Second, when looking at the probabilities in panel B of the table we find that the probability of self-employed persons remaining self-employed throughout the period 1987-1999 is comparatively low. The decrease in the diagonal entries is greatest in the state of self-employment when comparing the short-run model in panel A of the table to the long-run model in panel B. In all, this would suggest that there is a great deal of alternation between self-employment and other labour market states.

The ergodic distributions implied by the transition functions show that the tendencies in the study period are towards self-employment and non-employment in urban labour markets, while in rural labour markets it is only towards non-employment (Table 3). The ergodic probability of being self-employed in the urban labour markets is 0.060 , whereas the share of self-employed in the initial situation, 1987 was 0.049 and in the final situation, 19990.056 . The corresponding shares in the rural labour markets were 0.094 and 0.080 , while the ergodic probability is 0.095 . The rate of self-employment, i.e. the share of self-employed to all employed, based on the ergodic distribution is, however, comparatively high in both types of labour market. These 
steady state rates rise, because the ergodic probabilities of being in wage work remain fairly low (due to the tendency of paid-employment to fall over the period).

$==$ Table 3 around here $==$

\section{Alternating working careers}

The preceding analysis showed evidence of a considerable amount of dynamics in the labour markets, and above all that the transition probabilities between different labour market states for rural and urban areas differ significantly. In estimating the transition probabilities we assumed that the process of change can be described in terms of one-step transitions. The process of change can, however, be more complex: the state occupied by an individual at time $t$ may also depend on states at previous times. Next we analyse alternation between self-employment and other labour market states among individuals. We also test our hypotheses on the effects of environmental and individual characteristics.

\subsection{A descriptive analysis}

We are interested whether alternation is greater in rural than in urban areas, knowing that rural locations suffer from declining employment as a result of a shrinking agricultural employment base and the failure of alternative forms of economic activity to emerge sufficiently. The above analysis also showed a higher, although declining rate of self-employment, and greater transition probabilities from paid- and non-employment to self-employment in rural than urban areas.

Table 4 indicates that alternation between self-employment and other labour market states is indeed more common in rural than in urban areas. The proportion of serial entrepreneurs, i.e. those individuals with frequent entries to and exits from self-employment, is relatively big in rural locations: $3.4 \%$ of all individuals transited to self-employment and $2.2 \%$ switched from self-employment at least twice in the twelve-year period, compared to $2.1 \%$ and $1.2 \%$ in urban areas. The average period of self-employment among the self-employed is longer in rural than in urban locations, suggesting the existence of a larger "core" of self-employed individuals in rural areas.

$==$ Table 4 around here $==$

Table 5 gives more detailed information on the distribution of the different working career patterns in the two areas. The most noteworthy finding is that rural dwellers show more alternation in their working careers than urban dwellers. The proportion of those who have been both in paid- and self-employment is nearly five and the proportion of those with self-employment and non-employment experience four percentage points higher in rural than in urban areas. Furthermore, the proportion of those who have been in all three labour market states is $9 \%$ in rural areas and $6 \%$ in urban areas. Career paths are evidently more varied in rural than urban locations.

$==$ Table 5 around here $==$ 
To describe alternating working careers more thoroughly, individuals with both paid- and self-employment experience $(n=2374)$ were extracted from the data in order to reveal natural groupings, or clusters, within this data set on the basis of information on each individual's labour market states for each year of the study period. The procedure used is TwoStep Cluster Analysis, which also works with categorical variables in contrast to traditional clustering techniques. ${ }^{7}$ It should be noted that the classification can be expected to be affected by censoring, as we cannot observe the states for the years before 1987 and after 1999. This is, however, not so critical here, as our main purpose is a comparison of urban and rural labour markets.

The clustering produced five distinct categories of individuals with alternating careers (Table 6). The first category consists of those individuals who transited from a short period of paid-employment to self-employment; the second of those who, after a lengthy period of self-employment, transited to paid work; the third of those who only at the end of the period transited to self-employment, after a lengthy period in paid- and non-employment; the fourth of those who were most of the time non-employed, but were in self- and paid-employment at the beginning of the period; and the fifth of those who were most of the time in paid work, but were self- and non-employed at the beginning.

$==$ Table 6 around here $==$

All these five categories are represented in both areas, although there is some variation in their distributions. Category 2 - those who transited to paid work after a lengthy period of self-employment - is strongly represented in rural areas, while category 5 - those who were chiefly in paid work after being self- and non-employed for a short time at the outset - is relatively well represented in urban areas. It should, however, be noted that alternation between different labour market states in aggregate is more common, and the relative number of those who show alternation in their working careers is greater, in rural than in urban areas. If we take this into account, each category is represented better in rural locations than in urban locations.

\subsection{Logit and multinomial logit analyses}

The descriptive analysis supports our hypothesis that individuals with alternating working careers are more likely to reside in rural than urban locations. To test this more thoroughly, we carry out multivariate analyses in which the dependent variable separates those with alternating worker careers from the others. First, a logit model is estimated with a dependent variable which was assigned the value of one if an individual had been in both paid- and self-employment during the period $(n=2007)$, and zero if not. Second, a multinomial logit model is estimated with a dependent variable based on the clustering result above. Thus, the reference class remains the same as in the logit model, whereas individuals with alternating working careers form five categories (cf. Table 6).

The categorical variables used in the cluster analysis are the 13 variables which describe an individual's occupational status (labour market state) in each year of the period. The likelihood measure is used as a distance measure. This assumes that variables in the cluster model are independent and have a multinomial distribution. The procedure determines the "best" number of clusters, using the Bayesian Information Criterion. 


\section{Variables and hypotheses}

The aim is to analyse alternation between labour market states, not yearly transitions from one state to another as in many self-employment studies. The urban-rural dummy describes the situation in the local labour market and no other region-specific variables are included in the analysis. This is because we want to test the effect of different environments through the urban-rural variable. It is evident that differences between urban and rural labour markets follow from the different structural factors characterizing these areas, in this case mainly from the fact that rural labour markets are lacking employment opportunities.

In addition to an explanatory variable describing whether an individual resides in a rural or urban area, important individual-level variables are included in the analysis. The Appendix presents a description of the variables used. The variables describing personal and family characteristics are standard variables used in many analyses of self-employment, describing age, gender, education and family relations (cf. Parker 2004). The effect of many personal characteristics may, however, vary depending on the motives for entrepreneurship, i.e. whether entrepreneurship is opportunity-driven or necessity-based. Unfortunately, we cannot separate the different motives for self-employment in our data. It is then partly an empirical question as to whether and in which way these characteristics are related to alternating working careers.

The effect of age may be non-linear, for which reason both age and age squared are included in the models. Ageing is assumed to increase necessity-based self-employment, but middle age is expected to increase opportunity-driven entrepreneurship. A dummy indicates whether the individual is female or not. Men are expected more than women to have alternating working careers. A language dummy shows whether the individual belongs to the Swedish-speaking segment of the population. Finland is a bilingual country where Finnish is the dominant language. The Swedish-speaking community with its shared language, culture and social capital may increase opportunity-driven entrepreneurship as well as self-employment dynamics (Liebkind, Broo and Finnäs 1995).

Two education variables separate those with an intermediate and a higher level of education from those with a basic education. The role of education in self-employment is a complex one. Education may increase an individual's probability of becoming self-employed, as it enhances his/her human capital; but higher earning capacity, which arises due to a higher level of education may also depress this probability. Finnish results suggest that individuals with a higher level of education have a lower probability of entering self-employment (Johansson 2000; Uusitalo 2001; Niittykangas and Tervo 2005). Kangasharju and Pekkala (2002) found a lower exit probability for firms run by highly educated individuals during the economic downturn, whereas it was higher during the economic upturn. We expect low education to increase necessity-based self-employment, while higher education is expected to increase opportunity-driven entrepreneurship. In addition, two dummies indicate the main educational orientations, the first separating those with a commercial education and the second those with a technical education. Commercial education, especially, is expected to increase both types of entrepreneurship.

Two variables indicate the individual's family status, the first one showing whether (s)he is married or cohabiting, and the second one whether the household has more than two members (indicating families with children). While necessity-based self-employed individuals are largely expected to have a family and children, family situation is not assumed to differentiate between opportunity-driven entrepreneurs. 
The results of the estimations show, first of all, that the urban-rural dummy obtains a statistically significant coefficient in all cases: the probability that an individual will have an alternating working career clearly increases if (s)he lives in a rural location. In the logit estimation, the effect is clear. In the multinomial logit estimation, the coefficients vary somewhat, depending on the type of working career. The effect of a rural location seems to be especially strong among those who transited to paid-employment after a lengthy period of self-employment (category 2). An obvious explanation for this is the declining trend in self-employment in rural areas since 1993, reflecting diminishing local demand and an ageing population.

The behaviour of personal and family variables is in most cases as expected. Age is in non-linear relationship with alternation: middle-aged individuals have a higher probability of an alternating working career than younger or older individuals. The logit estimation shows that individuals who were around age 30-32 at the beginning of the study period and age 42-44 at the end of the period have highest probability of an alternating career. This, however, varies somewhat, depending on the category, as age has no significant effect in categories 4 and 5 .

Gender has a strong effect on alternation in working careers - men are more likely than women to choose (or to drift into) an alternating working career. Mother tongue has no impact. Contrary to our expectations, self-employment dynamics does not increase among the Swedish-speaking community. The logit estimation shows that both an intermediate and a higher level of education somewhat increase the probability of alternation in the working career. The multinomial logit estimation shows a somewhat varying effect, depending on the category. In category 4, which contains those individuals who were non-employed for most of the period, higher education obtains a statistically significant negative coefficient. The logit model shows that a commercial education increases the probability of change in the working career, while a technical education decreases it. In the multinomial logit estimations, however, these effects are not significant in every category. Marital status has a significant positive effect in every case, except for category 4 in the multinomial logit estimation where the effect of marriage is negative. Family size has a significant positive effect only in the logit estimation.

To illuminate the issue further, models with interaction terms between the urban-rural dummy and personal characteristics were also estimated (results are not shown here). In most cases, these interaction variables were insignificant, except in the multinomial logit estimation related to category 2, where the interaction between the urban-rural and female dummies was highly significant and positive (+0.84). In this specification, the urban-rural dummy obtained a smaller coefficient than in the initial specification (0.78 vs. 1.12), while the female dummy obtained a bigger negative coefficient (-1.01 vs. -0.54$)$. Thus, the pure regional effect is not quite as high as the first estimation without this interaction term implied. These results suggest that females in rural areas have a relatively high probability of having an alternating working career in which transition into paid work takes place after a lengthy period of self-employment. This might result from the fact that self-employed women often work in service industries, a sector which in particular suffers from diminishing local demand in rural areas.

\section{Conclusions and policy implications}


While serial entrepreneurship has been increasingly studied (e.g. Hyytinen and Ilmakunnas 2006), the issue of transitions and alternations between self-employment and other labour market states is rarely addressed. This paper shows that the functioning of regional labour markets is complex. Individuals' choices between paid work, self-employment and non-employment are not always predetermined, and some may switch from paid-employment to self-employment or non-employment, and the other way round.

Self-employment is an important option, especially in areas which have fewer paid-employment opportunities. For many individuals in these locations, alternation between different labour market states, i.e. paid-employment, self-employment and non-employment, becomes a necessity. Rural labour markets in Finland are characterized by lower rates of employment, self-sufficiency in jobs and dependency than urban labour markets. Historically, rural areas have suffered from depopulation and declining employment due to overdependence on a shrinking agricultural sector, low population density and the failure of sufficient alternative forms of economic activity to emerge. In consequence, entrepreneurship in these areas tends to be necessity-based (cf. Carrasco and Ejrnæs 2003). This result would suggest that the level of necessity-based entrepreneurial activity in Finland is higher than the GEM results indicate (Heinonen, Kovalainen and Pukkinen 2006).

The analysis showed that career choices are affected by environmental factors. Serial entrepreneurship and alternation between different labour market states is more common in rural than urban labour markets in Finland. The Markovian analysis showed differences in the transition processes between the three basic labour market states in rural compared to urban areas. Individuals with alternation in their working careers are more likely to reside in rural locations than prima facie might be expected. Five major types of working careers were identified in the data. Multivariate analyses showed the type of area, whether urban or rural, is importantly related to alternating working careers even when all the important variables describing personal and family characteristics are included in the models. This result was obtained irrespective of the type of alternating working career.

Many individuals in rural labour markets are pushed into self-employment or non-employment, as employment opportunities remain low. Role models may also explain this. Rural labour markets have a strong tradition of entrepreneurship, which creates a good seedbed for self-employment. On the other hand, flows out of self-employment have also become great since rural locations suffer from low levels of demand and entrepreneurial ability may remain low.

Regional competitiveness has varied greatly in Finland, the most competitive regions being those containing an urban centre. The danger for many rural regions is depopulation, a process which cumulatively tends to destroy jobs and retard development in these areas while at the same time benefiting a few big centres. Alternating working careers become more and more important for individuals remaining in these areas. Encouraging migration in general may not improve the geographical matching of jobs and the unemployed. Migration alone is not a very effective mechanism for alleviating unemployment on the individual level (Pekkala and Tervo 2002; Tervo 2005). What is needed is a policy which supports people who want to stay and earn their living in rural areas. If paid work is scarce, entrepreneurship and alternating working careers should be encouraged.

In Finland the government has launched the Entrepreneurship Policy Programme as a part of its economic and industrial policy. This programme aims at general improvements in the conditions for entrepreneurship, but the main focus is on concrete projects that support entrepreneurship. The programme consists of different sub-sectors such as entrepreneurial 
training and consultancy and regional entrepreneurship. Our findings suggest that in Finnish entrepreneurship policy more emphasis should be put on measures that would increase the desirability of entrepreneurship as a career option and which would also enable alternation between entrepreneurship and paid work. This is especially important in rural areas where alternation can be decisive in making it possible to earn a living.

One area in which improvement is needed are the regulations governing social and unemployment benefits, as these are worse for self-employed than for wage earners. These regulations are especially complicated in the case of alternating working careers (cf. Holm and Onnela 2004). Awkward regulations do not encourage individuals to take up entrepreneurship, even if they drift into unemployment. These regulations need to be changed to correspond to those relating to paid-employment. This would give unemployed individuals a further incentive to start a business of their own. Self-employment may only remain an intermediate phase for many in their total career, but nevertheless it contributes to continuation in the career. It is also more likely to end in paid work than in non-employment.

This is one of the first papers to address alternation between different labour market states, and so leaves considerable room for further research. For example, the factors affecting transitions (entries and exits) between labour market states merit more thorough analysis. We also need further analysis of the determinants of duration with respect to different states. Answers to these questions are required before we can fully understand the role of alternating working careers in different labour markets.

Acknowledgements. An earlier version of this paper was presented at the 44th ERSA conference held in Porto. The paper forms part of research projects number 200856 and number 112116 (LIIKE2-project) financed by the Academy of Finland. The author wishes to thank the Yrjö Jahnsson Foundation for financial support, Hannu Niittykangas for discussions on the topic and three referees and Jouke van Dijk, the editor of this journal, for helpful comments and suggestions.

\section{References}

Alanen A (1997) Change in the number of firms in the countryside (in Finnish). Maaseudun Uusi Aika 1/97: 110-118.

Audretsch DB (1990) The technological regime and small firm turbulence. International Small Business Journal 9: 80-97

Banerjee AV, Newman AF (1993) Occupational choice and the process of development. Journal of Political Economy 101: 279-298

Becker G (1975) Human capital. Columbia University Press, New York

Beesley ME, Hamilton RT (1984) Small firms' seedbed role and the concept of turbulence. The Journal of Industrial Economics 23: 217-231

Bickenbach F, Bode E (2003) Evaluating the Markov property in studies of economic convergence. International Regional Science Review 26: 363-392

Blanchflower DG (2000) Self-employment in OECD countries. Labor Economics 7:471-505

Carrasco R (1999) Transitions to and from self-employment in Spain: an empirical analysis. Oxford Bulletin of Economics and Statistics 61:315-341

Carrasco R, Ejrnæs M (2003) Self-employment in Denmark and Spain: institution, economic conditions and gender differences. Centre for Applied Microeconometrics, Institute of Economics, University of Copenhagen

Carroll GR, Mosakowski E (1987) The career dynamics of self-employment. Administrative Science Quarterly 32: 570-589

Curran J, Storey D (1993) The location of small and medium enterprises: are there urban-rural differences? In: Curran J, Storey D (eds.) Small firms in urban and rural locations. Routledge, London and New York 
Evans DS, Leighton LS (1989a) Some empirical aspects of self-employment. The American Economic Review 79(3): 519-535

Evans DS, Leighton LS (1989b) The determinants of changes in US self-employment, 1967-1987. Small Business Economics 1:111-119

Heinonen J, Kovalainen A, Pukkinen T (2006) Global entrepreneurship monitor: 2005 Executive Report Finland. Turku School of Economics and Business Administration, Business Research and Development Centre, Series B 2, Lahti

Holm P, Onnela M (2004) Changing working careers and unemployment insurance. Does unemployment insurance encourage entrepreneurship? (In Finnish) Pellervo Economic Research Institute Working Papers 67, Helsinki

Hyytinen A, Ilmakunnas P (2004) Entrepreneurial aspirations. The Research Institute of the Finnish Economy Discussion Papers 890, Helsinki

Hyytinen A, Ilmakunnas P (2006) What distinguishes a serial entrepreneur? Helsinki Center of Economic Research, Discussion Paper 111

Johansson E (2000) Essays on the determinants of self-employment. Publications of the Swedish School of Economics and Business Administration, $\mathrm{Nr} 85$, Helsingfors

Jovanovic B (1982) Selection and the evolution of industry. Econometrica 50: 649-670

Kangasharju A (2000) Regional variations in firm formation: panel and cross-section data evidence from Finland. Papers in Regional Science 79: 355-374

Kangasharju A, Pekkala S (2002) The role of education in self-employment success in Finland. Growth and Change 33 (2):216-237

Knight F (1921) Risk, uncertainty, and profit. Houghton Mifflin, New York

Kuhn PJ, Schuetze HJ (2001) Self-employment dynamics and self-employment trends: a case study of Canadian men and women, 1982-1998. Canadian Journal of Economics 34(3)

Lévesque M, Shepherd DA, Douglas EJ (2002) Employment or self-employment: a dynamic utility-maximizing model. Journal of Business Venturing 17(3):189-210

Liebkind K, Broo R, Finnäs F (1995) The Swedish-speaking minority in Finland. In Cultural Minorities in Finland: An Overview Towards Cultural Policy, Publications 66, Finnish National Commission for Unesco

Lin Z, Picot G, Compton J (2000) The entry and exit dynamics of self-employment in Canada. Small Business Economics 15: 105-125

Malecki EJ (1997) Technology \& economic development. The dynamics of local, regional and national competitiveness. Longman, London

Moyes A and Westhead P (1990) Environments for new firm formation in Great Britain. Regional Studies 24: 123-136

Niittykangas H (1999) Entrepreneurship and the countryside (in Finnish). Kuopio University Occasional Reports E. Social Sciences 9. Kuopio

Niittykangas H (2003) Entrepreneur and the operational environment of the entreprise (in Finnish). University of Jyväskylä. School of Business and Economics Publications 134, Jyväskylä

Niittykangas H, Nenonen T (1994) The formation of new firms by people living in non-urban settings. Papers in Regional Science 73: 393-406

Niittykangas H, Storhammar E, Tervo H (1994) Entrepreneurship and the birth of firms in local environments (in Finnish). University of Jyväskylä, Centre for Economic Research Publications 132, Jyväskylä

Niittykangas H, Tervo H. (2005) Spatial variations in intergenerational transmission of self-employment. Regional Studies 39: 319-332

Parker SC (2004) The economics of self-employment and entrepreneurship. Cambridge University Press, Cambridge

Pekkala S, Tervo H (2002) Unemployment and migration: does moving help? The Scandinavian Journal of Economics 104: 621-639

Rey SJ (2004) Spatial dependence in the evolution of regional income distributions. In: Getis A, Mur J, Zoeller H (eds.) Spatial Econometrics and Spatial Statistics. Palgrave

Reynolds P, Storey DJ, Westhead P (1994) Cross-national comparisons of the variation in new firm formation rates. Regional Studies 28: 443-456

Ritsilä J, Tervo H (2002) Effects of unemployment on new firm formation: micro-level panel data evidence from Finland. Small Business Economics 14:31-40

Schumpeter JA (1966) Capitalism, socialism and democracy. Unwin, London

Shorrock A (1978) The measurement of mobility. Econometrica 46: 1013-1024

Storey DJ (1994) Understanding the small business sector. Routledge, London 
Statistics Finland (2001) Population Census 2000 Handbook, Helsinki

Taylor MP (1999) Survival of the fittest. An analysis of self-employment duration in Britain. Economic Journal 109: C140-C155

Tervo H (2005) Regional policy lessons from Finland. In: Felsenstein D, Portnov BA (eds.) Regional disparities in small countries. Springer-Verlag, Berlin

Tervo H (2006) Regional unemployment, self-employment and family background. Applied Economics 38: 1055-1062

Tervo H, Haapanen M (2005) Self-employment duration in urban and rural locations. Porto: Regional Science Association International \& European Regional Science Association- 44th European Congress, August 27- 30, 2004. CD - rom.

Tervo H, Niittykangas H (1994a) The impact of unemployment on new firm formation in Finland. International Small Business Journal 13(1):38-53

Tervo H, Niittykangas H (1994b) Developments in the growth, location and turbulence of business services in Finland. Papers in Regional Science 73 (1):1-23

Uusitalo R (2001) Homo entreprenaurus? Applied Economics 33:1631-1638

Wagner J, Stenberg R (2002) The role of the regional milieu for the decision to start a new firm: empirical evidence for Germany. IZA Discussion papers 494 / Institute for the Study of Labor

Wennekers S, van Stel A, Thurik R, Reynolds P (2005) Nascent entrepreneurship and the level of economic development. Small Business Economics 24: 293-309

Westhead P, Birley S (1994) Environments for business deregistrations in the United Kingdom, 1987-1990. Entrepreneurship and Regional Development 6:29-62 
Table 1. Differences between employment opportunities in rural and urban labour markets

\begin{tabular}{llc}
\hline Feature & Urban areas & Rural areas \\
\hline $\begin{array}{l}\text { Employment rate, \% (1993) } \\
\begin{array}{l}\text { Self-sufficiency in jobs (number of jobs compared with the number } \\
\text { of employed in an area, 1992) }\end{array}\end{array}$ & 60.3 & 57.5 \\
$\begin{array}{l}\text { Dependency rate (number of unemployed persons and persons } \\
\text { outside the labour force for each employed person, 1993) }\end{array}$ & 1.43 & 1.72 \\
\hline
\end{tabular}


Table 2. Estimated Markov chain transition probabilities for urban and rural labour markets; three labour market states

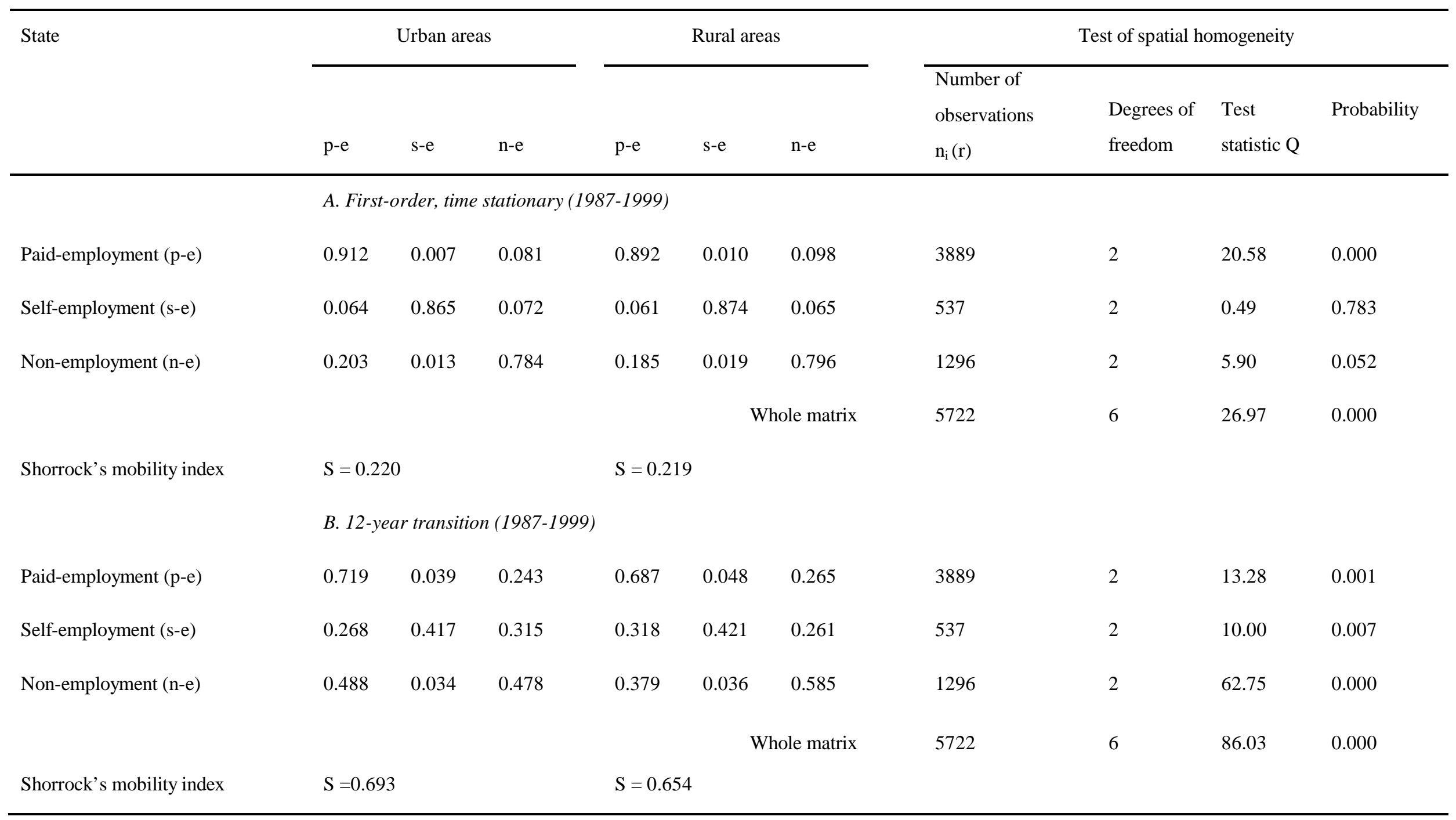


Table 3. Comparisons of initial (1987), final (1999) and ergodic distributions in urban and rural labour markets; three labour market states

\begin{tabular}{|c|c|c|c|c|c|c|c|c|}
\hline \multirow[b]{2}{*}{ Distribution } & \multicolumn{4}{|c|}{ Urban areas } & \multicolumn{4}{|c|}{ Rural areas } \\
\hline & $\begin{array}{l}\text { Paid- } \\
\text { employment }\end{array}$ & $\begin{array}{l}\text { Self- } \\
\text { employment }\end{array}$ & $\begin{array}{l}\text { Non- } \\
\text { employment }\end{array}$ & $\begin{array}{l}\text { Rate of self- } \\
\text { employment }\end{array}$ & $\begin{array}{l}\text { Paid- } \\
\text { employment }\end{array}$ & $\begin{array}{l}\text { Self- } \\
\text { employment }\end{array}$ & $\begin{array}{l}\text { Non- } \\
\text { employment }\end{array}$ & $\begin{array}{l}\text { Rate of self- } \\
\text { employment }\end{array}$ \\
\hline Initial, $\mathrm{t}$ & 0.767 & 0.049 & 0.184 & 0.060 & 0.680 & 0.094 & 0.226 & 0.121 \\
\hline Final, $t+1$ & 0.654 & 0.056 & 0.290 & 0.079 & 0.583 & 0.080 & 0.337 & 0.121 \\
\hline Ergodic, $\infty$ & 0.669 & 0.060 & 0.272 & 0.082 & 0.591 & 0.095 & 0.314 & 0.138 \\
\hline $\begin{array}{l}\text { Ergodic based on } \\
12 \text {-year transitions } \\
\text { (B) }\end{array}$ & 0.618 & 0.060 & 0.324 & 0.088 & 0.542 & 0.069 & 0.389 & 0.113 \\
\hline
\end{tabular}


Table 4. A comparison of inflows, outflows and years in self-employment in urban and rural areas

\begin{tabular}{llll}
\hline & & $\begin{array}{l}\text { Urban areas } \\
(\mathrm{n}=13489)\end{array}$ & $\begin{array}{l}\text { Rural areas } \\
(\mathrm{n}=5725)\end{array}$ \\
\hline $\begin{array}{l}\text { Number of transitions per individual into } \\
\text { self-employment in 1987-1999; } \%\end{array}$ & 0 & 88.1 & 80.8 \\
$\begin{array}{l}\text { (also includes those who were self-employed in the first } \\
\text { year of the period, 1987) }\end{array}$ & 1 & 9.7 & 15.8 \\
& 2 or more & 2.1 & 3.4 \\
$\begin{array}{l}\text { Number of transitions per individuals out of } \\
\text { self-employment in 1987-1999, } \%\end{array}$ & All & 100.0 & 100.0 \\
& 0 & 92.6 & 87.4 \\
& 1 & 6.2 & 10.4 \\
\hline $\begin{array}{l}\text { Average years in self-employment in 1987-1999 } \\
\text { (among those who have been self-employed) }\end{array}$ & 2 or more & 1.2 & 100.0 \\
\hline
\end{tabular}


Table 5. Basic data on different working careers in 1987-1999 in urban and rural areas

\begin{tabular}{llll}
\hline & & Urban areas & Rural areas \\
\hline In paid-employment & All 12 years & $37.4 \%$ & $29.7 \%$ \\
& No years & $6.9 \%$ & $12.3 \%$ \\
In self-employment & All 12 years & $1.5 \%$ & $3.2 \%$ \\
& No years & $88.1 \%$ & $80.8 \%$ \\
In non-employment & All 12 years & $4.1 \%$ & $6.7 \%$ \\
Only paid-employment or self-employment & No years & $42.0 \%$ & $37.6 \%$ \\
Paid-employment and self-employment & & $86.8 \%$ & $79.5 \%$ \\
Self-employment and non-employment & & $9.1 \%$ & $13.7 \%$ \\
All three labour market states & & $7.4 \%$ & $11.3 \%$ \\
\hline
\end{tabular}


Table 6. A typology of alternating working careers ${ }^{1}$

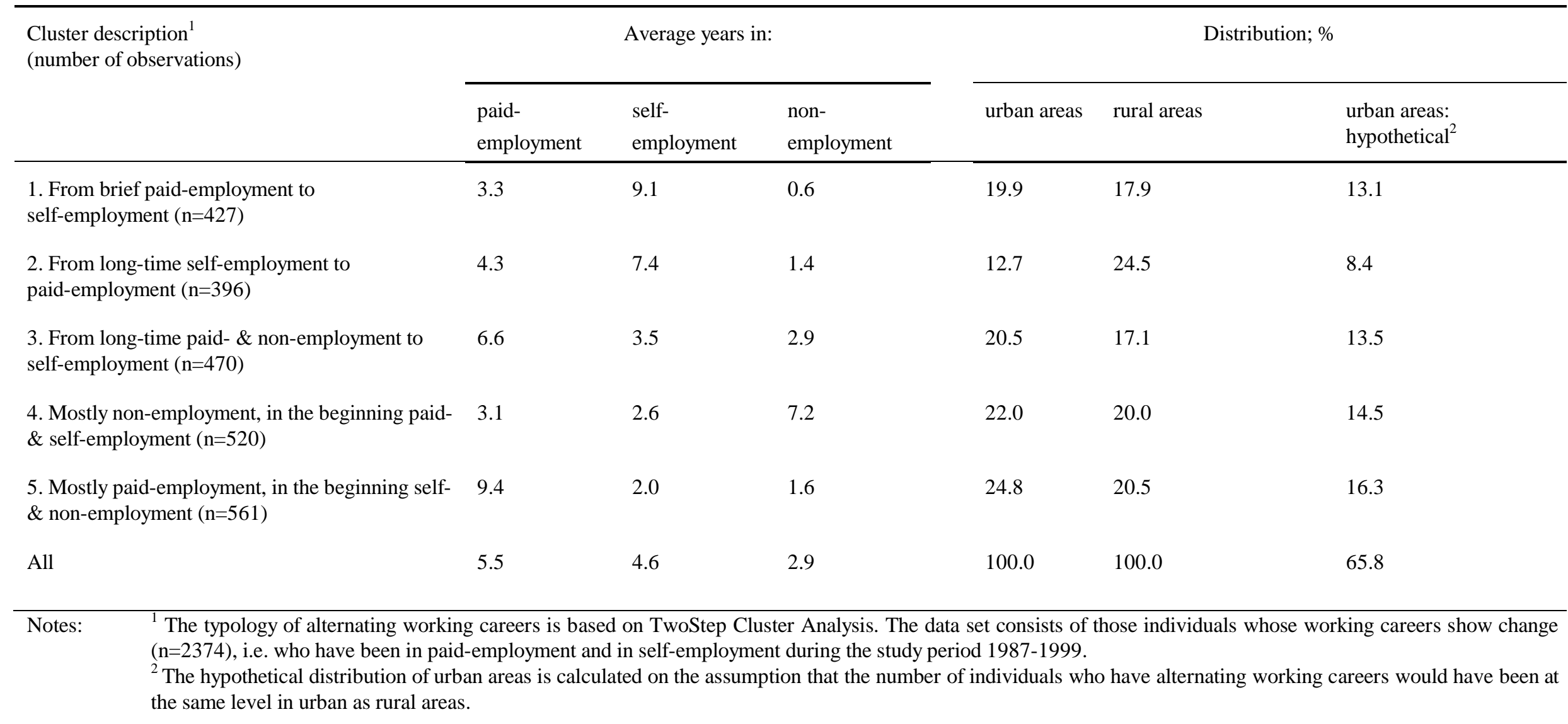


Table 7. Logit and multinomial logit estimations

\begin{tabular}{|c|c|c|c|c|c|c|}
\hline \multirow[t]{2}{*}{ Variable } & \multirow{2}{*}{$\begin{array}{l}\text { Logit } \\
\text { model: } \\
\text { coefficients } \\
\text { (standard } \\
\text { errors) }\end{array}$} & \multicolumn{5}{|c|}{ Multinomial logit model: coefficients (standard errors) } \\
\hline & & Category 1 & Category 2 & Category 3 & Category 4 & Category 5 \\
\hline Rural & $\begin{array}{l}0.47 * * * \\
(0.05)\end{array}$ & $\begin{array}{l}0.34 * * \\
(0.11)\end{array}$ & $\begin{array}{l}1.12 * * * \\
(0.11)\end{array}$ & $\begin{array}{l}0.31 * * \\
(0.11)\end{array}$ & $\begin{array}{l}0.33 * * \\
(0.10)\end{array}$ & $\begin{array}{l}0.33 * * \\
(0.10)\end{array}$ \\
\hline Age & $\begin{array}{l}0.10^{* * * *} \\
(0.02)\end{array}$ & $\begin{array}{l}0.20 * * * \\
(0.05)\end{array}$ & $\begin{array}{l}0.33^{* * *} \\
(0.06)\end{array}$ & $\begin{array}{l}0.08 \\
(0.05)\end{array}$ & $\begin{array}{l}0.04 \\
(0.04)\end{array}$ & $\begin{array}{l}0.04 \\
(0.04)\end{array}$ \\
\hline $\mathrm{Age}^{2} / 100$ & $\begin{array}{l}-0.16 * * * \\
(0.03)\end{array}$ & $\begin{array}{l}-0.30 * * * \\
(0.11)\end{array}$ & $\begin{array}{l}-0.45 * * * \\
(0.08)\end{array}$ & $\begin{array}{l}-0.21 * * \\
(0.08)\end{array}$ & $\begin{array}{l}-0.05 \\
(0.06)\end{array}$ & $\begin{array}{l}-0.10 \\
(0.06)\end{array}$ \\
\hline Female & $\begin{array}{l}-0.56 * * * \\
(0.05)\end{array}$ & $\begin{array}{l}-0.89 * * * \\
(0.12)\end{array}$ & $\begin{array}{l}-0.54 * * * \\
(0.12)\end{array}$ & $\begin{array}{l}-0.66 * * * \\
(0.12)\end{array}$ & $\begin{array}{l}-0.49 * * * \\
(0.11)\end{array}$ & $\begin{array}{l}-0.35^{* *} \\
(0.11)\end{array}$ \\
\hline Swedish-speaking & $\begin{array}{l}0.05 \\
(0.11)\end{array}$ & $\begin{array}{l}0.07 \\
(0.23)\end{array}$ & $\begin{array}{l}0.27 \\
(0.22)\end{array}$ & $\begin{array}{l}-0.20 \\
(0.27)\end{array}$ & $\begin{array}{l}-0.32 \\
(0.27)\end{array}$ & $\begin{array}{l}0.21 \\
(0.20)\end{array}$ \\
\hline $\begin{array}{l}\text { Intermediate level of } \\
\text { education }\end{array}$ & $\begin{array}{l}0.23 * * \\
(0.07)\end{array}$ & $\begin{array}{l}0.39 * \\
(0.16)\end{array}$ & $\begin{array}{l}0.35^{*} \\
(0.16)\end{array}$ & $\begin{array}{l}0.17 \\
(0.16)\end{array}$ & $\begin{array}{l}0.08 \\
(0.14)\end{array}$ & $\begin{array}{l}0.24 \\
(0.15)\end{array}$ \\
\hline $\begin{array}{l}\text { Higher level of } \\
\text { education }\end{array}$ & $\begin{array}{l}0.15^{*} \\
(0.08)\end{array}$ & $\begin{array}{l}0.02 \\
(0.18)\end{array}$ & $\begin{array}{l}0.29 \\
(0.17)\end{array}$ & $\begin{array}{l}0.14 \\
(0.17)\end{array}$ & $\begin{array}{l}-0.41 * \\
(0.17)\end{array}$ & $\begin{array}{l}0.63 * * * \\
(0.15)\end{array}$ \\
\hline $\begin{array}{l}\text { Field of education: } \\
\text { commercial }\end{array}$ & $\begin{array}{l}0.20 * * \\
(0.08))\end{array}$ & $\begin{array}{l}0.55^{* *} \\
(0.16)\end{array}$ & $\begin{array}{l}0.10 \\
(0.18)\end{array}$ & $\begin{array}{l}0.24 \\
(0.16)\end{array}$ & $\begin{array}{l}0.25 \\
(0.17)\end{array}$ & $\begin{array}{l}-0.09 \\
(0.14)\end{array}$ \\
\hline $\begin{array}{l}\text { Field of education: } \\
\text { technical }\end{array}$ & $\begin{array}{l}-0.16^{*} \\
(0.07)\end{array}$ & $\begin{array}{l}-0.08 \\
(0.15)\end{array}$ & $\begin{array}{l}-0.24 \\
(0.16)\end{array}$ & $\begin{array}{l}-0.07 \\
(0.15)\end{array}$ & $\begin{array}{l}-0.17 \\
(0.15)\end{array}$ & $\begin{array}{l}-0.27 * \\
(0.14)\end{array}$ \\
\hline Married or cohabiting & $\begin{array}{l}0.31 * * * \\
(0.06)\end{array}$ & $\begin{array}{l}0.68 * * * \\
(0.16)\end{array}$ & $\begin{array}{l}0.44 * * \\
(0.15)\end{array}$ & $\begin{array}{l}0.52 * * \\
(0.15)\end{array}$ & $\begin{array}{l}-0.25^{*} \\
(0.12)\end{array}$ & $\begin{array}{l}0.40 * * \\
(0.13)\end{array}$ \\
\hline Family with children & $\begin{array}{l}0.15^{*} \\
(0.06)\end{array}$ & $\begin{array}{l}0.25 \\
(0.13)\end{array}$ & $\begin{array}{l}-0.00 \\
(0.13)\end{array}$ & $\begin{array}{l}0.18 \\
(0.13)\end{array}$ & $\begin{array}{l}0.18 \\
(0.12)\end{array}$ & $\begin{array}{l}0.11 \\
(0.12)\end{array}$ \\
\hline Constant & $\begin{array}{l}-3.74 * * * \\
(0.34)\end{array}$ & $\begin{array}{l}-6.02 * * * \\
(0.86)\end{array}$ & $\begin{array}{l}-8.43 * * * \\
(1.00)\end{array}$ & $\begin{array}{l}-3.93 * * * \\
(0.82)\end{array}$ & $\begin{array}{l}-5.04 * * * \\
(0.77)\end{array}$ & $\begin{array}{l}-3.13 * * * \\
(0.70)\end{array}$ \\
\hline Number of individuals & 19214 & 19182 & & & & \\
\hline $\begin{array}{l}\text { Number of individuals } \\
\text { who have alternating } \\
\text { working careers }\end{array}$ & 2007 & 382 & 347 & 383 & 425 & 463 \\
\hline$-2 \log$ likelihood & 12491.2 & 10328.8 & & & & \\
\hline Model khii2 & $367.6 * * *$ & $662.8 * * *$ & & & & \\
\hline
\end{tabular}

Logit model: dependent variable has $(=1)$ / has not $(=0)$ had changes in working career (been in both paid-employment and self-employment). Multinomial logit model: dependent variable a typology (1-5) of alternating working careers (see Table 6), reference category "no alternating working career".

$* * * / * * / *$ statistically significant at the $0.001 / 0.01 / 0.05$ level. 


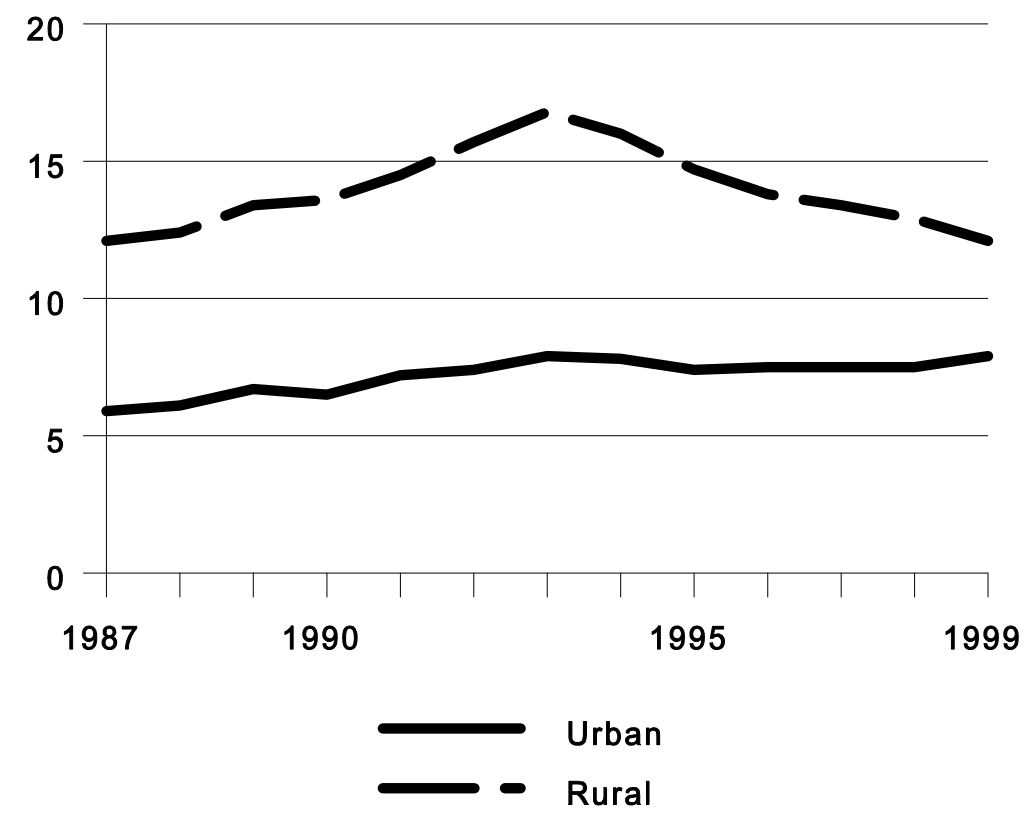

Figure 1. Non-agricultural self-employment rates (\%) in urban and rural labour markets 1987-1999 


\section{Urban labour markets}

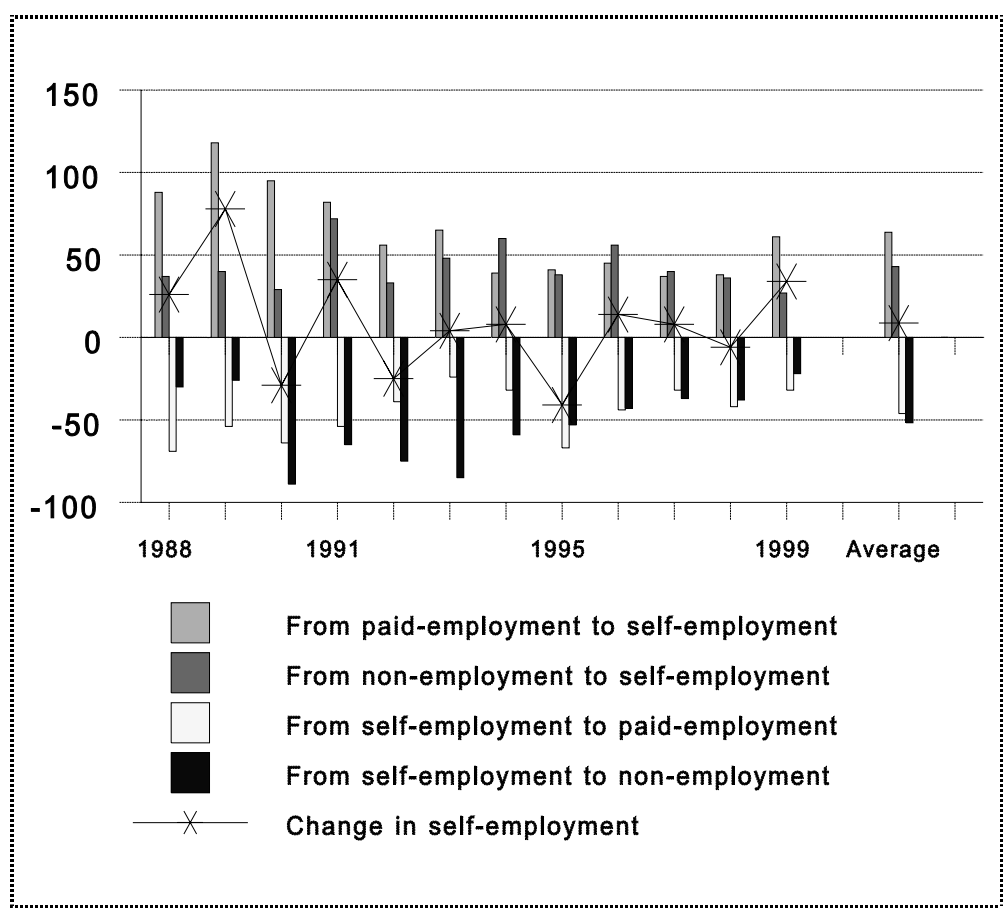

\section{Rural labour markets}

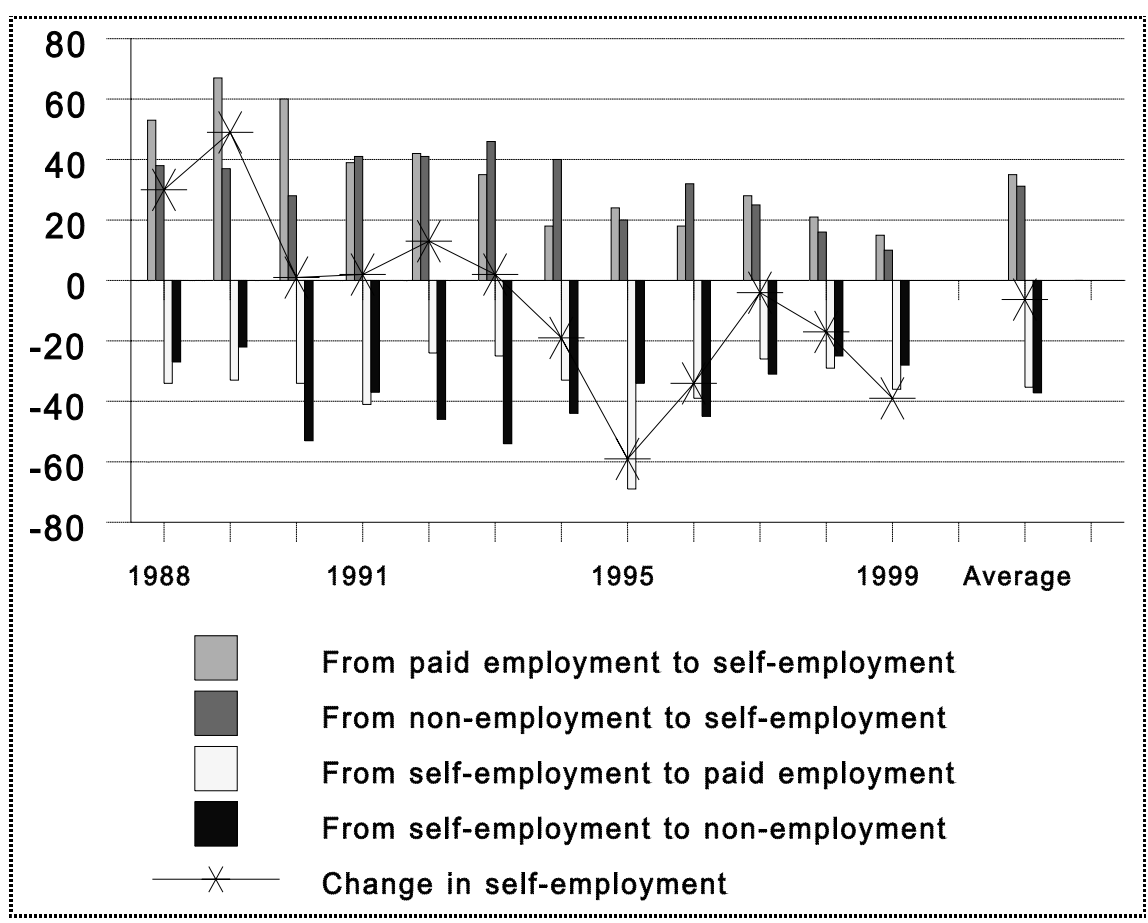

Figure 2. Flows into and out of self-employment in 1987-1999 (number of individuals in the sample) 
Appendix. Descriptions of explanatory variables and their means

\begin{tabular}{|c|c|c|}
\hline Variable & Description & Mean \\
\hline Rural & $\begin{array}{l}1 \text { if an individual resided in a rural area throughout the study period } \\
1987-1999,0 \text { if in an urban area }\end{array}$ & 0.298 \\
\hline Age & Age in years in 1987 & 34.55 \\
\hline $\operatorname{Age}^{2} / 100$ & Age squared divided by 100 & 12.81 \\
\hline Female & 1 if female, 0 if male & 0.509 \\
\hline Swedish-speaking & 1 if Swedish-speaking, 0 otherwise (1998) & 0.048 \\
\hline \multicolumn{3}{|c|}{ Level of education - reference category basic education } \\
\hline - intermediate & 1 if secondary education (1998), 0 otherwise & 0.381 \\
\hline - higher & 1 if tertiary education (1998), 0 otherwise & 0.309 \\
\hline \multicolumn{3}{|c|}{ Field of education - reference category other fields } \\
\hline - commercial & 1 if field of education commercial (1998), 0 otherwise & 0.152 \\
\hline - technical & 1 if field of education technical (1998), 0 otherwise & 0.244 \\
\hline $\begin{array}{l}\text { Married or } \\
\text { cohabiting }\end{array}$ & 1 if married or cohabiting (1998), 0 if single & 0.720 \\
\hline Family with children & 1 if more than two persons in the household (1998), 0 otherwise & 0.513 \\
\hline
\end{tabular}

